Journal of Education and Teaching Learning (JETL)

Volume 4, Issue 1, January 2022

Journal Homepage:

http://pusdikra-publishing.com/index.php/jetl

\title{
Snowball Throwing Learning Model : Increase Student Activity And Learning Outcomes
}

Kartika Manalu1, Efrida Pima Sari Tambunan², Oki Permata Sari ${ }^{3}$

1,2,3 Universitas Islam Negeri Sumatera Utara, Indonesia

Corresponding Author : okipermatasari39@gmail.com

\begin{tabular}{|c|c|}
\hline & ABSTRACT \\
\hline $\begin{array}{l}\text { ARTICLE INFO } \\
\text { Article history: } \\
\text { Received } \\
\text { 03 February } 2022 \\
\text { Revised } \\
\text { 09 February } 2022 \\
\text { Accepted } \\
\text { 16 February } 2022\end{array}$ & $\begin{array}{l}\text { This study aims to describe the snowball throwing learning model to } \\
\text { increase student activity and learning outcomes. In this study, the } \\
\text { method used was an experimental type using a quasi-experimental } \\
\text { approach. Data collection techniques with the help of questionnaires, } \\
\text { tests and documentation. To test the data analysis using the normality } \\
\text { test, homogeneity test and hypothesis testing. The results of the study } \\
\text { showed that there was a stimulus to student learning activity that was } \\
\text { influenced by the Snowball Throwing learning model. It was } \\
\text { indicated by an increase in the active category of } 65.6 \% \text {. Active } \\
\text { learning using the Snowball Throwing model Also shows the very } \\
\text { active category in the experimental class with a percentage of } 95.6 \% \text {. } \\
\text { Learning with the Snowball Throwing method also affects the value of } \\
\text { learning outcomes, there is an increase in the value from the category } \\
\text { that does not meet the KKM score to a good category in meeting the } \\
\text { KKM score. Based on the t-test obtained with a value of } 7.424>\text { t-table } \\
2.001 \text {, it shows that the Snowball Throwing learning model has } \\
\text { contributed to the effectiveness and learning outcomes of students in } \\
\text { class VIII Mts } 1 \text { PAB Helvetia, Deli Serdang Regency. }\end{array}$ \\
\hline Key Word & Snowball Throwing, Student, Learning \\
\hline How to cite & https://pusdikra-publishing.com/index.php/jetl/issue/view/50 \\
\hline Doi & 10.51178/jetl.v4i1.413 \\
\hline & $\begin{array}{c}\text { CC (†) (O) } \\
\text { This work is licensed under a } \\
\text { Creative Commons Attribution-ShareAlike } 4.0 \text { International License }\end{array}$ \\
\hline
\end{tabular}

\section{PENDAHULUAN}

Pentingnya hasil belajar pada saat belajar mengajar sangat diperlukan. Karena adanya hasil belajar dapat mengukur kemampuan peserta didik, sejauh mana mereka mampu menerima pembelajaran dari pendidik. Terutama pada aspek pengetahuan dan sikap dimana pendidik bisa menyampaikan isi materi pelajaran dengan baik terhadap peserta didik. Hasil belajar ini memberi acuan kepada peserta didik supaya lebih giat dalam belajar agar dapat memperoleh hasil belajar yang sesuai dengan tujuan pembelajaran (Sudjana, 2013). Keaktifan siswa dalam proses pembelajaran menyebabkan interaksi yang tinggi antara guru dan siswa maupun sebaliknya antara siswa dan guru. Hal ini menyebakan suasan menjadi kondusif siswa mampu melibatkan kemampuan semaksimal 
mungkin. Aktivitas atau keaktifan yang timbul dari siswa akan mengakibatkan terbentuknya pengetahuan dan keterampilan yang akan mengarahkan kepada prestasi belajar. Keaktifan belajar tidak hanya dituntut dari segi fisik tetapi juga dari segi psikis (Gultom, 2020; Habibbulloh \& Arifin, 2019; Syamsul Bahri, 2021).

Metode Snowball Throwing merupakan salah satu model pembelajaran kooperatif. Metode pembelajaran tersebut mengandung unsur-unsur pembelajaran kooperatif. Snowball artinya bola salju sedangkan throwing artinya melempar. Snowball Throwing dapat diartikan sebagai metode pembelajaran yang menggunakan bola pertanyaan dari kertas yang digulung bulat berbentuk bola kemudian dilemparkan secara bergiliran di antara sesama anggota kelompok. Snowball Throwing yaitu metode pembelajaran yang didalam terdapat unsur-unsur pembelajaran kooperatif sebagai upaya dalam rangka mengarahkan perhatian siswa terhadap materi yang disampaikan oleh guru (Yuliati, 2015). Pada beberapa pembelajaran yang terjadi, metode Snowball Throwing memang mampu memberikan peningkatan keaktifan dalam pembelajaran dan juga memberikan hasil belajar siswa yang lebih baik. Dibuktikan dengan adanya peningkatan kognitif siswa (Hardini \& Akmal, 2017). Siswa yang diberikan metode pembelajaran dengan menggunakan Snowball Throwing akan lebih aktif, hal ini dikarenakan model pembelajaran dikemas seperti sebuah permainan dengan menarik, model ini dapat melatih psikomotorik siswa, kemampuan berpikir sehingga meningkatkan kemampuan siswa dalam menjawab pertanyaan-pertanyaa yang diberikan. Tidak hanya itu, siswa juga lebih leluasa dalam mengikuti pembelajaran, siswa bebas mengemukakan pendapatnya dan juga pembelajaran yang ditimbulkan lebih kondusif (Wardhiana et al., 2013).

Berdasarkan pengamatan di MTs 1 PAB Helvetia Deli Serdang, pada mata pelajaran IPA, guru masih menggunakan model ceramah dengan media papan tulis untuk menerangkan pelajaran kepada siswa. Hal tersebut dikarenakan kurangnya fasilitas berupa sarana dan prasarana di ruang kelas seperti LCD dan Infocus. Penggunaan model pembelajaran yang konvensional seperti metode ceramah menyebabkan siswa kurang antusias terhadap pelajaran yang disampaikan dan sering berbicara dengan teman sebangku, bermain handphone, dan mengerjakan pekerjaan rumah (PR) pada mata pelajaran lain karena merasa bosan. Pada mata pelajaran Ilmu Pengetahuan Alam kelas VIII, dari jumlah siswa sebanyak 30 siswa, hanya beberapa siswa yang aktif bertanya dan menjawab pertanyaan dari guru dalam kegiatan pembelajaran. Siswa bersikap diam saat diberi kesempatan bertanya dan menjawab pertanyaan. Dengan kata lain pembelajaran disekolah tersebut masih berorientasi pada 
guru yang bersifat menggunakan metode ceramah, kondisi pembelajaran tersebut jika berlangsung terus menerus akan bermuara pada rendahnya hasil belajar siswa. Serta kurangnya keberanian siswa dalam bertanya, kemampuan siswa dalam menjawab soal pun masih sangat kurang.

Dengan demikian penelitian ini memilih kelas VIII sebagai kelas eksperimen. Dan dapat diperoleh informasi bahwa kurangnya antusias siswa saat proses pembelajaran, model pembelajaran yang digunakan oleh guru cenderung monoton dan berpusat pada guru, guru kurang optimal memanfaatkan model pembelajaran, pertanyaan yang diajukan guru kurang direspon oleh siswa, kurangnya kerja sama antar siswa, serta rendahnya nilai yang diperoleh kebanyaan siswa masih rendah yaitu dibawah 75 yang merupakan Nilai Kriteria Ketuntasan Maksimal. Adapun nilai rata-rata Ujian Tengah Semester (UTS) siswa sebagai berikut :

\section{Tabel 1.}

Nilai Rata-Rata Ujian Tengah Semester (UTS) Siswa

\begin{tabular}{|c|c|c|}
\hline No & Kelas & Nilai Rata-Rata \\
\hline 1 & VIII-A & 48,67 \\
\hline 2 & VIII-B & 48,47 \\
\hline
\end{tabular}

Pada akhirnya pembelajaran dengan model ini diharapkan dapat meningkatkan hasil belajar dan keaktifan siswa dalam pembelajaran serta dapat meningkatkan kesan yang mendalam dan menjadikannya sebagai suatu pengalaman pembelajaran. Berdasarkan uraian teori, hasil penelitian dan permasalah sehinggga penelitian ini tertarik untuk meneliti beberapa masalah dalam pembelajaran yang dialami di MTs 1 PAB Jl. Veteran, Pasar IV Helvetia Kab. Deli Serdang.

\section{METODE PENELITIAN}

Penelitian ini meruapakan penelitian eksperimen dengan jenis penelitiannya adalah eksperimen semu. Penelitian eksperimen semu adalah eksperimen yang dilakukan karena tidak mungkin dapat mengontrol semua variabel yang turut mempengaruhi terhadap variabel terikat (Sitorus, 2011).

Penelitian ini akan dilaksanakan di MTs 1 PAB Jl. Veteran, Pasar IV Helvetia Kab. Deli Serdang Kec. Labuhan Deli. Waktu penelitian dilaksanakan pada semester ganjil Tahun Ajaran 2020/2021. Sedangkan untuk desain penelitian menggunakan rancangan seperti berikut ini 
Tabel 2.

Rancangan Penelitian Pre Test Dan Post Test

\begin{tabular}{|c|c|c|c|}
\hline Kelas & Pre Test & Perlakuan & Post Test \\
\hline Ekperimen & $\mathrm{O}_{1}$ & $\mathrm{X}_{1}$ & $\mathrm{O}_{2}$ \\
\hline Kontrol & $\mathrm{O}_{3}$ & $\mathrm{X}_{2}$ & $\mathrm{O}_{4}$ \\
\hline
\end{tabular}

\section{Keterangan}

$\mathrm{X}_{1}$

: Pembelajaran Dengan Menggunakan model Snowball Throwing

$\mathrm{X}_{2}$

: Pembelajaran Menggunakan Model Konvensiona (ceramah)

$\mathrm{O}_{1}$ dan $\mathrm{O}_{3} \quad$ : Kedua kelompok melakukan test awal (pre test)

$\mathrm{O}_{2} \quad$ : Kelompok eksperimen melakukan test akhir (post test)

$\mathrm{O}_{4} \quad$ : Kelompok kontrol melakukan test akhir (post test)

Teknik pengumpulan data pada penelitian ini yaitu dengan menggunakan angket, tes dan dokumentasi. Sedangkan dalam analisis data menggunakan uji normalitas, uji homogenitas dan uji hipotesis. Uji hipotesis dilakukan Untuk melihat apakah terdapat perbedaan yang signifikan antara hasil belajar kedua kelompok sekaligus menjawab hipotesis penelitian, maka dilakukan analisis statistik-t dengan taraf signifikan $\alpha=0,05$ dan derajat kebebasan $=n_{1}+n_{2}-2$.

$$
\mathrm{t}=\frac{x 1-x 2}{\sqrt[s]{\frac{1}{n 1}}+\frac{1}{n 2}} \text { dengan } S^{2}=\frac{(n 1-1) S_{1}^{2}+(n 2-1) S_{2}^{2}}{n 1+n 2-2}
$$

\section{HASIL PENELITIAN DAN PEMBAHASAN}

\section{Hasil Penelitian}

\section{Keaktifan Belajar Siswa Kelas Eksperimen}

Penilaian keaktifan belajar siswa dilakukan sebanyak empat kali saat proses pembelajaran berlangsung, yaitu pada pertemuan pertama, pertemuan kedua, pertemuan ketiga, dan pertemuan keempat. Adapun hasil angket keaktifan belajar siswa pada kelas eksperimen pada pertemuan pertama, kedua, ketiga, dan keempat.

Persentase keaktifan belajar siswa kelas eksperimen. Dimana indikator pertama yaitu visual activites diperoleh nilai persentase $80 \%$ (sangat aktif), mengalami peningkatan pertemuan kedua $88 \%$ (sangat aktif), mengalami peningkatan pada pertemuan ketiga 90\% (sangat aktif), dan pada pertemuan keempat mengalami peningkatan 100\% (sangat aktif). Indikator yang kedua Oral Activities dimana pada indikator ini ada II pernyataan, dengan pernyataan I didepatkan prestasi 80\% (aktif), mengalami peningkatan dipertemuan kedua yaitu sebesar $88 \%$ (sangat aktif), mengalami peningkatan pada pertemuan ketiga $88 \%$ (sangat aktif), dan pada pertemuan keempat mengalami peningkatan 98\% (sangat aktif). Pada pernyataan yang ke II mengalami prestasi $80 \%$ (aktif), mengalami peningkatan pada pertemuan kedua menjadi 83\% 
(sangat aktif), mengalami peningkatan pada pertemuan ketiga 86\% (sangat aktif), dan pada pertemuan keempat mengalami peningkatan 92\% (sangat aktif). Indikator yang ketiga Listening Activities dimana pada indikator ini ada II pernyataan, dengan pernyataan I didepatkan prestasi 83\% (aktif), mengalami peningkatan dipertemuan kedua yaitu sebesar 83\% (aktif), mengalami peningkatan pada pertemuan ketiga $87 \%$ (sangat aktif), dan pada pertemuan keempat mengalami peningkatan $93 \%$ (sangat aktif).pada pernyataan yang ke II mengalami persentase $82 \%$ (aktif), mengalami peningkatan pada pertemuan kedua menjadi $84 \%$ (sangat aktif), mengalami peningkatan pada pertemuan ketiga 91\% (sangat aktif), dan pada pertemuan keempat mengalami peningkatan 95\% (sangat aktif).

Indikator yang keempat Writing Activities dimana pada indikator ini ada II pernyataan, dengan pernyataan I didepatkan prestasi $80 \%$ (aktif), mengalami peningkatan dipertemuan kedua yaitu sebesar 90\% (sangat aktif), mengalami peningkatan pada pertemuan ketiga 91\% (sangat aktif), dan pada pertemuan keempat mengalami peningkatan $98 \%$ (sangat aktif).pada pernyataan yang ke II mengalami prestasi $81 \%$ (aktif), mengalami peningkatan pada pertemuan kedua menjadi $89 \%$ (sangat aktif), mengalami peningkatan pada pertemuan ketiga 90\% (sangat aktif), dan pada pertemuan keempat mengalami peningkatan 93\% (sangat aktif). Indikator yang kelima Motor Activities dimana didapatkan persentase $80 \%$ (aktif), mengalami peningkatan dipertemuan kedua yaitu sebesar 90\% (sangat aktif), mengalami peningkatan pada pertemuan ketiga 91\% (sangat aktif), dan pada pertemuan keempat mengalami peningkatan 90\% (sangat aktif). Indikator yang keenam Mental Activities dimana didapatkan persentase $83 \%$ (aktif), mengalami peningkatan dipertemuan kedua yaitu sebesar 92\% (sangat aktif), mengalami peningkatan pada pertemuan ketiga 91\% (sangat aktif), dan pada pertemuan keempat mengalami peningkatan 100\% (sangat aktif). Indikator yang keenam Emotional Activities dimana didapatkan persentase 80\% (aktif), mengalami peningkatan dipertemuan kedua yaitu sebesar 90\% (sangat aktif), mengalami peningkatan pada pertemuan ketiga 91\% (sangat aktif), dan pada pertemuan keempat mengalami peningkatan 100\% (sangat aktif).

\section{Keaktifan Belajar Siswa Kelas Kontrol}

Terlihat bahwa prestasi keaktifan belajar siswa kelas kontrol. Dimana indikator pertama yaitu visual activites diperoleh nilai persentase 35\% (tidak aktif), mengalami peningkatan pertemuan kedua 37\% (kurang aktif), mengalami peningkatan pada pertemuan ketiga $40 \%$ (kurang aktif), dan pada pertemuan keempat mengalami peningkatan 53\% (cukup aktif). Indikator yang kedua Oral Activities dimana pada indikator ini ada II pernyataan, dengan 
pernyataan I didepatkan prestasi 30\% (tidak aktif), mengalami peningkatan dipertemuan kedua yaitu sebesar 36\% (kurang aktif), mengalami peningkatan pada pertemuan ketiga 52\% (cukup aktif), dan pada pertemuan keempat mengalami peningkatan $80 \%$ (aktif). Pada pernyataan yang ke II mengalami prestasi $40 \%$ (kurang aktif), mengalami peningkatan pada pertemuan kedua menjadi 50\% (kurang aktif), mengalami peningkatan pada pertemuan ketiga $51 \%$ (cukup aktif), dan pada pertemuan keempat mengalami peningkatan 55\% (cukup aktif). Indikator yang ketiga Listening Activities dimana pada indikator ini ada II pernyataan, dengan pernyataan I didepatkan prestasi 20\% (tidak aktif), mengalami peningkatan dipertemuan kedua yaitu sebesar 45\% (kurang aktif), mengalami peningkatan pada pertemuan ketiga 60\% (cukup aktif), dan pada pertemuan keempat mengalami peningkatan 56\% (cukup aktif). Pada pernyataan yang ke II mengalami persentase 37\% (kurang aktif), mengalami peningkatan pada pertemuan kedua menjadi 38\% (kurang aktif), mengalami peningkatan pada pertemuan ketiga $61 \%$ (cukup aktif), dan pada pertemuan keempat mengalami peningkatan $75 \%$ (aktif).

Indikator yang keempat Writing Activities dimana pada indikator ini ada II pernyataan, dengan pernyataan I didepatkan prestasi 30\% (tidak aktif), mengalami peningkatan dipertemuan kedua yaitu sebesar 60\% (cukup aktif), mengalami peningkatan pada pertemuan ketiga $40 \%$ (kurang aktif), dan pada pertemuan keempat mengalami peningkatan $74 \%$ (aktif). Pada pernyataan yang ke II mengalami prestasi 30\% (tidak aktif), mengalami peningkatan pada pertemuan kedua menjadi 29\% (tidak aktif), mengalami peningkatan pada pertemuan ketiga $60 \%$ (cukup aktif), dan pada pertemuan keempat mengalami peningkatan $72 \%$ (aktif). Indikator yang kelima Motor Activities dimana didapatkan persentase $28 \%$ (tidak aktif), mengalami peningkatan dipertemuan kedua yaitu sebesar 30\% (tidak aktif), mengalami peningkatan pada pertemuan ketiga 35\% (tidak aktif), dan pada pertemuan keempat mengalami peningkatan $62 \%$ (cukup aktif). Indikator yang keenam Mental Activities dimana didapatkan persentase 31\% (tidak aktif), mengalami peningkatan dipertemuan kedua yaitu sebesar $40 \%$ (kurang aktif), mengalami peningkatan pada pertemuan ketiga 49\% (kurang aktif), dan pada pertemuan keempat mengalami peningkatan 59\% (cukup aktif). Indikator yang keenam Emotional Activities dimana didapatkan persentase 25\% (kurang aktif), mengalami peningkatan dipertemuan kedua yaitu sebesar 30\% (kurang aktif), mengalami peningkatan pada pertemuan ketiga $45 \%$ (kurang aktif), dan pada pertemuan keempat mengalami peningkatan $70 \%$ (aktif). Adapun grafik keaktifan belajar siswa pada kelas eksperimen pada pertemuan pertama, kedua, ketiga,keempat dapat dilihat pada grafik sebagai berikut : 
Grafik 1.

Keaktifan belajar Siswa Kelas Kontrol dan Eksperimen

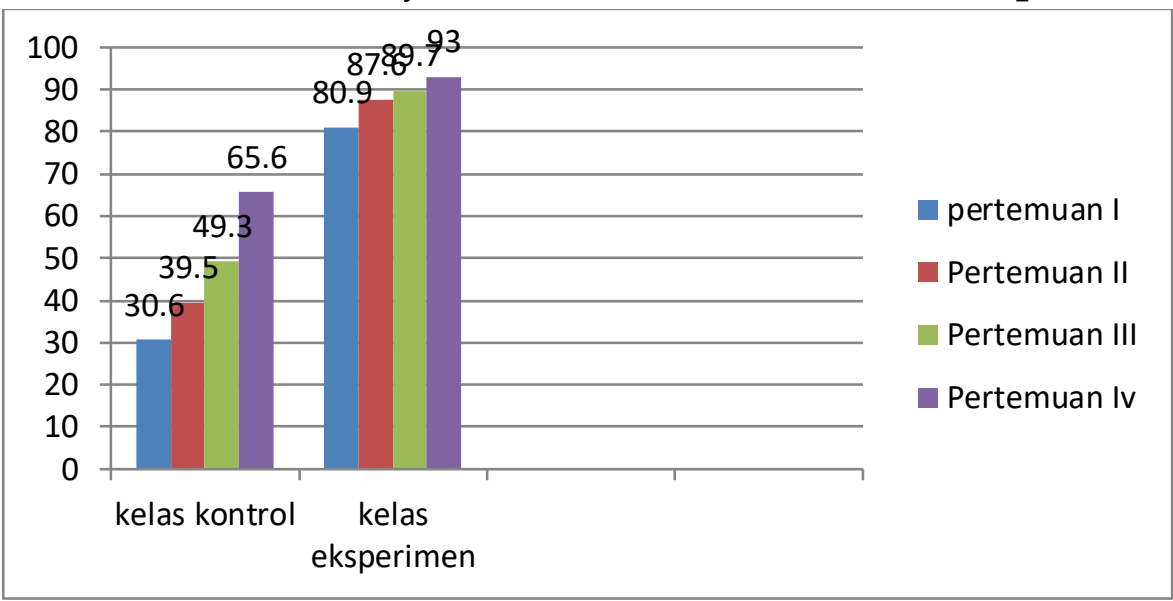

Berdasarkan Grafik diatas dapat diketahui bahwa presentasi keaktifan belajar siswa pada pertemuan pertama diperoleh $81 \%$ (aktif), sedangkan nilai yang diperoleh pada pertemuan yang kadua $88 \%$ (sanagt aktif), sedangkan nilai yang diperoleh pada pertemuan yang ketiga 90\% (sangat aktif), sedangakan pertemuan yang keempat $96 \%$ (sangat aktif). Selisih dari nilai rata-rata yang diperoleh dalam keaktifan belajar siswa di kelas eksperimen yaitu 7\%. Pada kelas kontrol pada pertemuan pertama diperoleh 31\% (tidak aktif), sedangkan nilai yang diperoleh pada pertemuan yang kedua 40\%(kurang aktif), sedangkan nilai yang diperoleh pada pertemuan yang ketiga 50\% (kurang aktif), sedangakan pertemuan yang keempat 66\% (cukup aktif). Selisih dari nilai ratarata yang diperoleh dalam keaktifan belajar siswa di kelas kontrol yaitu $10 \%$.

\section{Analisis Data Keaktifan Belajar Siswa}

Adapun analisis uji normalitas pada saat pretest dan posttest di kelas eksperimen dan kontrol dapat dilihat pada tabel diwabah ini :

Tabel 2.

Hasil Uji Normalitas Keaktifan Belajar Siswa

\begin{tabular}{|l|l|l|l|}
\hline \multicolumn{1}{|c|}{ Kelas } & \multicolumn{1}{c|}{ Lhitung $_{\text {Ltabel }}$} & Keterangan \\
\hline Eksperimen & 0,100 & 0,164 & Normal \\
\hline Kontrol & 0,154 & 0,164 & Normal \\
\hline
\end{tabular}

Dengan menggunakan tingkat signifikasi 0,5\% diperoleh bahwa Lhitung < $L_{\text {tabel }}$ maka data berdistribusi normal. Dari hasil perhitungan di atas dapat dilihat bahwa pada kelas eksperimen Lhitung 0,100, sedangkan $L_{\text {tabel }}=0,164$. Sehingga diperoleh Lhitung $<\mathrm{L}_{\text {tabel, }}$ maka dari itu data berdistribusi normal. Sedangkan pada kelas kontrol Lhitung 0,154 sedangkan $\mathrm{L}_{\text {tabel }}=0,164$. Sehingga diperoleh $\mathrm{L}_{\text {hitung }}<\mathrm{L}_{\text {tabel, }}$ maka dari itu data berdistribusi normal. analisis uji homogenitas eksperimen dan kontrol dapat dilihat pada tabel di bawah ini : 


\section{Tabel 3.}

\section{Hasil Uji Homogenitas Keaktifan Belajar Siswa}

\begin{tabular}{|l|l|l|l|l|}
\hline \multicolumn{1}{|c|}{ Kelas } & Varians & F $_{\text {hitung }}$ & $\mathbf{F}_{\text {tabel }}$ & Keteragan \\
\hline Eksperimen & 57,05 & 0,859 & 1,904 & Homogenitas \\
\hline Kontrol & 66,34 & 0,859 & 1,904 & Homogenitas \\
\hline
\end{tabular}

$\mathrm{F}_{\text {hitung }}$ Eksperimen $=\mathrm{S}_{1}{ }^{2} / \mathrm{S}_{2}{ }^{2}=0,859$

$F_{\text {hitung }}$ Kontrol $=S_{1}{ }^{2} / S_{2}{ }^{2}=0,859$

$\mathrm{F}_{\text {Tabel }}=$ Dk pembilang $=\mathrm{n}$ pembilang $-1=28-1=27$

Dk penyebut $=\mathrm{n}$ penyebut $-1=28-1=27$

Untuk nilai $F_{\text {tabel }}$ pada taraf nyata $\alpha 0,05$ diketahui bahwa apabila $F_{\text {hitung }}<$ $F_{\text {tabel }}$ maka data homogen. Dari tabel diatas dapat dilihat bahwa dk yang dimiliki adalah $27: 27$. Dk 27:27 adalah 1,904. Perbandingan $F_{\text {hitung }}$ dengan $F_{\text {tabel }}$ pada kelas eksperimen yaitu 0,547:1,904, yang mana $F_{\text {hitung }}<F_{\text {tabel }}$ maka data adalah homogen. Sedangkan Perbandingan $F_{\text {hitung }}$ dengan $F_{\text {tabel }}$ pada kelas kontrol yaitu 0,859: 1,904, yang mana $F_{\text {hitung }}<F_{\text {tabel }}$ maka data adalah homogen.

Pengujian hipotesis menggunakan Uji T-Test pada nilai Sig $=0,05$ dimana jika nilai Sig > 0,05 maka Ho diterima, sementara itu jika nilai Sig < 0,05 maka Ha diterima. Berdasarkan hasil perhitungan uji hipotesis diperoleh harga $\mathrm{T}_{\text {hitung }}$ $=12,2914$ dan $t_{\text {tabel }}=2,0012$ Dengan demikian diketahui bahwa $T_{\text {hitung }}=12,2914$ $>\mathrm{T}_{\text {tabel }}=2,0012$. Sehingga hipotesis nihil (H0) ditolak dan menerima hipotesis alternative (Ha) artinya ada pengaruh model pembelajaran snowball throwing terhadap keaktifan hasil belajar siswa kelas VIII MTs 1 PAB Helvetia Deli Serdang.

\section{Analisis Data Hasil Belajar Siswa}

\section{Tabel 4.}

Analisis Uji Homogenitas Pretest Dan Posttest Pada Kelas

Eksperimen Dan Kelas Kontrol

\begin{tabular}{|c|c|c|c|c|c|}
\hline Kelas & $\begin{array}{c}\text { Hasil } \\
\text { Belajar }\end{array}$ & $\mathbf{N}$ & $\mathbf{X}$ & SD & S2 $^{2}$ \\
\hline Eksperimen & Pretest & 28 & 53 & 6,869436 & 33,17294974 \\
\cline { 2 - 6 } & Posttest & 28 & 85 & 8,658345 & 63,71263228 \\
\hline \multirow{2}{*}{ Kontrol } & Pretest & 28 & 49 & 6,472878 & 6,713624 \\
\cline { 2 - 6 } & Posttest & 28 & 70 & 4,287918 & 29,876984127 \\
\hline
\end{tabular}

Fhitung Eksperimen $=\mathrm{S}_{1}{ }^{2} / \mathrm{S}_{2}{ }^{2}=0,520$

Fhitung Kontrol $=S_{1}{ }^{2} / S_{2}{ }^{2}=0,224$

$\mathrm{F}_{\text {Tabel }}=\mathrm{Dk}$ pembilang $=\mathrm{n}$ pembilang $-1=28-1=27$

Dk penyebut $=\mathrm{n}$ penyebut $-1=28-1=27$

Untuk nilai $\mathrm{F}_{\text {tabel }}$ pada taraf nyata $\alpha$ 0,05 diketahui bahwa apabila $\mathrm{F}_{\text {hitung }}<$ $F_{\text {tabel }}$ maka data homogen. Dari tabel diatas dapat dilihat bahwa dk yang 
dimiliki adalah 27:27. Dk 27:27 adalah 1,904. Perbandingan $F_{\text {hitung }}$ dengan $\mathrm{F}_{\text {tabel }}$ pada kelas eksperimen yaitu 0,520:1,904, yang mana $F_{\text {hitung }}<\mathrm{F}_{\text {tabel }}$ maka data

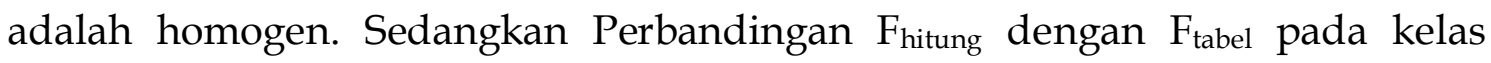
kontrol yaitu 0,224:1,904, yang mana $F_{\text {hitung }}<\mathrm{F}_{\text {tabel }}$ maka data adalah homogen.

Pada pengujian hipotesis ini menggunakan Uji T-Test pada nilai Sig $=0,05$ dimana jika nilai Sig > 0,05 maka Ho diterima, sementara itu jika nilai Sig $<0,05$ maka Ha diterima. Berdasarkan hasil perhitungan uji hipotesis diperoleh harga $\mathrm{T}_{\text {hitung }}=7,4246$ dan $\mathrm{t}_{\text {tabel }}=2,0012$ Dengan demikian diketahui bahwa $\mathrm{T}_{\text {hitung }}=$ $7,4246>\mathrm{T}_{\text {tabel }}=2,0012$. Sehingga hipotesis nihil $(\mathrm{H} 0)$ ditolak dan menerima hipotesis alternative (Ha) artinya ada pengaruh model pembelajaran snowball throwing terhadap hasil belajar siswa kelas VIII MTs 1 PAB Helvetia Deli Serdang.

\section{Pembahasan}

Metode model pembelajaran Snowball Throwing ini bertujuan untuk memancing keaktifan siswa dalam belajar sekaligus menguji daya setiap materi-materi yang disampaikan oleh ketua kelompok. Keaktifan belajar merupakan salah satu unsur dasar yang penting bagi keberhasilan proses pembelajaran. Aktif berarti giat dalam bekerja atau berusaha. Kegiatan bekerja dan berusaha dilakukan oleh siswa dalam proses pembelajaran sesuai dengan materi pelajaran yang disampaikan oleh guru. Keaktifan belajar merupakan kegiatan yang bersifat fisik maupun mental, yaitu berbuat dan berfikir sebagai suatu rangkaian yang tidak dapat dipisahkan (Wibowo, 2016). Hasil belajar merupakan hasil maksimum yang dicapai oleh seseorang setelah melakukan kegiatan belajar yang diberikan berdasarkan atas pengukuran tertentu(Lestiawan \& Johan, 2018).

Adanya kaitan antara keaktifan belajar siswa dan hasil belajar siswa dengan menggunakan model pembelajaran Snowball Throwing. Dimana dapat dilihat berdasarkan meningkatnya hasil presentase dari pertemuan pertama sampai dengan pertemuan keempat pada kelas eksperimen dan kelas kontrol, adapun rata-rata presentase kelas eksperimen pada pertemuan pertama sebesar 80,9\% kategori aktif, pada pertemuan kedua sebesar 87,6\% kategori sangat aktif, pada pertemuan ketiga sebesar $89,7 \%$ kategori sangat aktif, sampai dengan pada pertemuan keempat sebesar 95,6\% juga kategori sangat aktif. Sedangkan pada kelas kontrol rata-rata presentase didapatkan pada pertemuan pertama sebesar 30,6\% kategori tidak aktif, pada pertemuan kedua sebesar $39,5 \%$ kategori kurang aktif, pada pertemuan ketiga sebesar 49,3\% kategori kurang aktif, dan pada pertemuan keempat sebesar 65,6\% kategori aktif. Berdasarkan penelitian ini penggunaan model pembelajaran Snowball Throwing 
dapat meningkatkan keaktifan belajar siswa. Dengan demikian nilai $\mathrm{T}_{\text {hitung }}=$ 12,2914 dan $t_{\text {tabel }}=2,0012$ Dengan demikian diketahui bahwa $T_{\text {hitung }}=12,2914>$ $\mathrm{T}_{\text {tabel }}=2,0012$. Sehingga hipotesis nihil (H0) ditolak dan menerima hipotesis alternative (Ha) artinya ada pengaruh model pembelajaran snowball throwing terhadap keaktifan hasil belajar siswa kelas VIII MTs 1 PAB Helvetia Deli Serdang. Berdasarkan penelitian ini penggunaan model pembelajaran Snowball Throwing dapat meningkatkan keaktifan belajar siswa.

Penelitian yang sama menerangkan bahwa peningkatan keberhasilan guru dalam menerapkan model pembelajaran Snowball Throwing meningkat dari siklus I sebesar 79,44\% menjadi 90,05\%. Perbandingan aktivitas siswa juga menunjukkan peningkatan dari siklus I ke siklus II dengan persentase rata-rata siklus I $59,84 \%$ dan menjadi $76,08 \%$ pada siklus II, sehingga dapat menjamin peningkatan 15\%. Dapat dikatakan bahwa hasil belajar siswa kelas X IIS 1 SMA Brawijaya Smart School meningkat sebesar 3\% (Zaqiyaturrahmah, 2018).

Sedangkan hasil penelitian menunjukkan bahwa rata-rata nilai pretest pada kelas eksperimen yang diperoleh adalah sebesar 53 maka rata-rata hasil pretest siswa pada kelas eksperimen yang belum diberikan model pembelajaran Snowball Throwing dikategorikan kurang dalam memenuhi nilai KKM. Rata-rata untuk nilai posttest kelas eksperimen adalah sebesar 85 maka rata-rata nilai posttest siswa pada kelas eksperimen yang sudah diberikan perlakuan model pembelajaran Snowball Throwing dikategorikan baik dalam memenuhi nilai KKM. Rata-rata hasil nilai pretest siswa pada kelas kontrol adalah sebesar 49 maka rata-rata hasil nilai pretest siswa pada kelas kontrol yang belum diberikan perlakuan model pembelajaran konvensional dapat dikategorikan kurang dalam memenuhi nilai KKM. Dan rata-rata hasil nilai posttest siswa pada kelas kontrol adalah sebesar 70, maka rata-rata hasil nilai pretest siswa pada kelas kontrol yang sudah diberikan perlakuan model pembelajaran konvensional dikategorikan sebagai kurang dalam memenuhi nilai KKM. Selanjutnya hasil nilai posttest kelas eksperimen dan kontrol digunakan dalam analisis data tahap akhir. Analisis data pada tahap akhir menunjukkan kedua kelas berdistribusi normal dan kelompok sampel mempunyai varians yang homogen. Dan nilai rata-rata pada kelas eksperimen adalah sebesar 85 dikategorikan baik dalam memenuhi nilai KKM dan nilai rata-rata pada kelas kontrol adalah sebesar 70 dikategorikan kurang dalam memenuhi nilai KKM. Dengan demikian nilai $t_{\text {hitung }}$ sebesar 7,4246 $>t_{\text {tabel }} 2,0012$, maka berdasarkan dengan dasar pengambilan keputusan dapat disimpulkan bahwa $\mathrm{H}_{0}$ ditolak dan $\mathrm{Ha}$ diterima. Yang mana memiliki arti Terdapat pengaruh model pembelajaran snowball throwing terhadap keaktifan dan hasil belajar siswa kelas VIII MTs 1 PAB Helvetia Deli Serdang. Berdasarkan 
penelitian ini penggunaan model pembelajaran Snowball Throwing dapat meningkatkan hasil belajar siswa.

Model pembelajaran dengan menerapkan model pembelajaran Snowball Throwing jauh lebih efektif dibandingkan dengan menggunakan model pembelajaran konvensional (Saefudin \& Berdianti, 2015). Terlihat bahwa hasil belajar siswa kelas eksperimen yang menerapkan model pembelajaran Snowball Throwing memiliki nilai tertinggi dibandingkan dengan kelas kontrol yang menggunakan model pembelajaran konvensionl. Hal ini Snowball Throwing memiliki kelebihan suasana pembelajaran menjadi menyenangkan, siswa mendapat kesempatan untuk mengembangkan kemampuan berpikir karena diberi kesempatan untuk membuat pertanyaan, dan siswa lebih berperan aktif dalam pembelajaran berlangsung. Adanya peningkatan hasil pembelajaran, aktivitas siswa dan kinerja guru di akhir siklus. Hal ini membuktikan bahwa model pembelajaran Snowball Throwing dapat meningkatkan hasil belajar (Agustina, 2017; Aulia, 2019).

Berdasarkan hasil analisis data diketahui bahwa model pembelajaran Snowball Throwing yang digunakan dalam proses belajar mengajar dapat membuat siswa lebih aktif dalam belajar, serta dapat membuat siswa untuk lebih memahami materi yang dipelajari, sehingga dapat meningkatkan keaktifan dan hasil belajar siswa. Dikarenakan model Pembelajaran Snowball Throwing (melempar bola) merupakan jenis pembelajaran kooperatif yang didesain seperti permainan melempar bola.

\section{KESIMPULAN}

Temuan yang disajikan menunjukkan bahwa adanya pengaruh model pembelajaran Snowball Throwing terhadap keaktifan belajar siswa. Pada kelas kontrol dari pertemuan I sampai dengan pertemuan IV sebesar 65,6\% kategori sebagai aktif. Sementara hasil nilai rata-rata persentase keaktifan belajar siswa yang menggunakan model pembelajaran Snowball Throwing pada kelas eksperimen dari pertemuan I sampai dengan pertemuan IV sebesar 95,6\% kategori sebagai sangat aktif. Sehingga terdapat pengaruh keaktifan belajar siswa dengan menggunakan model pembelajaran Snowball Throwing. $T_{\text {hitung }}=$ 12,2914 dan $t_{\text {tabel }}=2,0012$ Dengan demikian diketahui bahwa $T_{\text {hitung }}=12,2914>$ $\mathrm{T}_{\text {tabel }}=2,0012$. Sehingga hipotesis nihil (H0) ditolak dan menerima hipotesis alternative (Ha) artinya ada pengaruh model pembelajaran snowball throwing terhadap keaktifan hasil belajar siswa kelas VIII MTs 1 PAB Helvetia Deli Serdang.

Adanya pengaruh model pembelajaran Snowball Throwing terhadap Hasil belajar siswa. Pada kelas kontrol nilai post test siswa memiliki nilai rata-rata 70 
dikategorikan kurang memenuhi nilai KKM dengan nilai terendah 65 dan nilai tertinggi 80. Pada kelas eksperimen hasil posttest menggunakan model pembelajaran Snowball Throwing memiliki rata-rata sebesar 85 dikategorikan baik dalam memenuhi nilai KKM dan rata-rata dengan nilai terendah 70 dan nilai tertinggi 95. Hasil nilai thitung sebesar 7,4246 > nilai tabel 2,0012, maka berdasarkan dengan dasar pengambilan keputusan melalui perbandingan nilai thitung dengan $\mathrm{t}_{\text {tabel }}$ dapat disimpulkan bahwa $\mathrm{H}_{0}$ ditolak dan $\mathrm{H}_{\mathrm{a}}$ diterima. Yang mana memiliki arti Terdapat pengaruh model pembelajaran snowball throwing terhadap keaktifan dan hasil belajar siswa kelas VIII MTs 1 PAB Helvetia Deli Serdang.

\section{PENGAKUAN}

Penelitian ini sebagai syarat untuk memenuhi penyelesaian studi tingkat sarjana di Universitas Islam Negeri Sumatera Utara Medan. MTs PAB Helvetia Deli Serdang sebagai wadah bagi penulis untuk mendalami proses pembelajaran yang menggunakan model Snowball Throwing.

\section{DAFTAR PUSTAKA}

Agustina, E. T. (2017). Implementasi Model Pembelajaran Snowball Throwing Untuk Meningkatkan Hasil Belajar Siswa Dalam Membuat Produk Kria Kayu Dengan Peralatan Manual. Innovation of Vocational Technology Education, 9(1). https://doi.org/10.17509/invotec.v9i1.4881

Aulia, M. S. F. F. W. (2019). Peningkatan Aktivitas Belajar Siswa Melalui Model Snowball Throwing di Sekolah Dasar. 3(3). https:// doi.org/https://doi.org/10.31004/ basicedu.v3i3.189

Gultom, D. (2020). Meningkatkan Hasil Belajar Siswa Dalam Reading: Memahami Makna Teks Tulis Fungsional Dan Esai Pendek Sederhana Berbentuk Narrative Dan Report Melalui Metode Snowball Drilling Di Kelas IX-B SMPN 2 Pahae Jae T.P 2016/2017. Journal Of Education And Teaching Learning (JETL), 2(2), 17-26. https:/ / doi.org/10.51178/jetl.v2i2.61 Habibbulloh, M., \& Arifin, A. (2019). The Efektivitas Model Pembelajaran Kooperatif Stad Menggunakan Alat Peraga Alquran Untuk Meningkatkan Penguasaan Tajwid. Jurnal Pendidikan Agama Islam, 16(2), 189-202. https:// doi.org/10.14421/jpai.2019.162-04

Hardini, A. T. A., \& Akmal, A. (2017). Penerapan Metode Snowball Throwing Berbantuan Media Konkret Untuk Meningkatkan Keaktifan Dan Hasil Belajar IPA Siswa Kelas IV Sekolah Dasar. JURNAL PENDIDIKAN DASAR PERKHASA: Jurnal Penelitian Pendidikan Dasar, 3(1). https:// doi.org/https://doi.org/10.31932/jpdp.v3i1.37 
Lestiawan, F., \& Johan, A. B. (2018). Penerapan Metode Pembelajaran Example Non Exsample Untuk Meningkatkan Keaktifan Dan Hasil Belajar DasarDasar Pemesinan. Jurnal Taman Vokasi, 6(1). https:// doi.org/https://doi.org/10.30738/jtv.v6i1.2866

Saefudin, A., \& Berdianti, I. (2015). Pembelajaran Efektif. PT Remaja Rosdakarya. Sitorus, M. (2011). Metodologi Penelitian Pendidikan Islam. IAIN PRESS.

Sudjana, N. (2013). Penilaian Hasil Proses Belajar Mengajar. Remaja Rosdakarya.

Syamsul Bahri, N. A. (2021). Kebijakan Pendidikan Dalam Stabilitas Mutu Pembelajaran Anak Usia Dini Era Pandemi Disease. Continuous Education: Journal of Science and Research, 2(2), 14-22. https:// doi.org/10.51178/ce.v2i2.224

Wardhiana, I. K. S., I. G. A. Agung S., N. W., \& Suniasih. (2013). Penerapan Model Pembelajaran Kooperatif Tipesnowball Throwing Untuk Meningkatkan Keaktifan Dan Hasil Belajar PKn Kelas V SD Negeri 1 Bungbungan. Mimbar PGSD Undiksha, 1(1). https:// doi.org/http://dx.doi.org/10.23887/jjpgsd.v1i1.1483

Wibowo, N. (2016). Upaya Peningkatan Keaktifan Siswa Melalui Pembelajaran Berdasarkan Gaya Belajar Di Smk Negeri 1 Saptosari. Elinvo (Electronics, Informatics, and Vocational Education), 1(2), 128-139. https:/ / doi.org/10.21831/elinvo.v1i2.10621

Yuliati. (2015). Efektifitas Penggunaan Model Kooperatif Tipe Snowball Throwing Untuk Meningkatkan Hasil Belajar Siswa Pada Materi Sistem Pertidaksamaan Linear Di Kelas XI-IS-2 Negeri 7 Banda Aceh. Jurnal Peluang, 2(1). http://jurnal.unsyiah.ac.id/peluang/article/view/5718 Zaqiyaturrahmah, E. (2018). Implementation Of Cooperative Learning Model Snowball Throwing To Increase Activity And Learning Outcomes. Classroom Action Research Journal (CARJO), 2(2). https:// doi.org/http://journal2.um.ac.id/index.php/carjo/article/view/ 6568 